\title{
Nature Restoration Shifts the Abundance and Structure of Soil Nematode Communities in Subtropical China
}

Jianqing Wang ( $\sim$ jianqingwang@aliyun.com )

Fujian Normal University https://orcid.org/0000-0002-8035-2756

\section{Yingfeng Zheng}

Fujian Normal University

\section{Xiuzhen Shi}

Fujian Normal University

\section{Shu Kee Lam}

The University of Melbourne

\author{
Manuel Esteban Lucas-Borja \\ Castilla-La Mancha University \\ Zhiqun Huang \\ Fujian Normal University
}

\section{Research Article}

Keywords: Chronosequence, forest soil, natural restoration, soil food web, subtropical forest

Posted Date: July 29th, 2021

DOl: https://doi.org/10.21203/rs.3.rs-740625/v1

License: (c) (i) This work is licensed under a Creative Commons Attribution 4.0 International License. Read Full License 


\section{Abstract}

Aims Soil nematode community is an important component of the soil food web, which has been widely recognized as a key bio-indicator for assessing the influence of nature restoration on ecological functions. However, the dynamics of the abundance, diversity and function of soil nematode community remain unclear under different forest succession phases.

Methods The soil nematode community of natural secondary forests was investigated using a chronosequence approach. Nature restoration for five succession stages were sampled in this study to represent a wide range of stand age groups.

Results Soil nematode abundance gradually increased with forest stand age, which reached a peak value (574 individuals $100 \mathrm{~g} \mathrm{~g}^{-1}$ dry soil) in the older age classes. In contrast, soil nematode diversity was not affected by forest stand age. Soil available nitrogen and phosphorus were key factors influencing soil nematode abundance and diversity during forest secondary succession. The plant parasite index decreased with forest stand age, which indicated that ecosystem function and health would be improved as nature restoration progresses. In addition, the structure of soil nematode community was more sensitive to forest secondary succession compared to plant community and soil microbial community. The bottom-up effects of the plant and microbial communities on soil nematode community were important drivers of nematode community structure in subtropical forests.

Conclusions Overall, this study demonstrates the active responses of soil nematode community to nature restoration, and highlights the importance of the above-ground and below-ground interactions to the soil food web.

\section{Introduction}

Global losses of natural habitats are rapidly eroding terrestrial biodiversity and are expected to increase the rate of species extinction (Fahrig, 2003; Tilman et al., 2017). Human activities such as logging, hunting, burning and cultivating, have adversely affected terrestrial ecosystems and damaged the environment, threatening the existence and function of many species (Betts et al., 2017; Renčo et al., 2015). In the last few decades, large proportions of subtropical forests are recovering from logging, fire and natural disturbances (Calderon-Aguilera et al., 2012; Pan et al., 2011). While vegetation succession and soil processes are interdependent (van der Putten et al., 2013; Wardle et al., 2004), there is a paucity of information on the effects of forest secondary succession on soil food webs.

The soil food web is essential to the provision of ecosystem services, such as biogeochemical nutrient cycling in terrestrial ecosystems (Van Den Hoogen et al., 2019; Wang et al., 2019; Wilschut and Geisen, 2020). In forest ecosystems, soil nematode has been considered as a key component of the soil food web and plays an important role in biodiversity and ecosystem services (Bongers and Bongers, 1998; Zhang et al., 2015). Nematode community composition and diversity vary with forest secondary succession (Dickie 
community structure (Amossé et al., 2016; Sohlenius, 2002). Interactions between plants and soil organisms can greatly vary with forest age (Kardol et al., 2006; van der Putten et al., 2013). Zhang et al. (2015) showed that the abundance and diversity of nematodes was the highest in the middle forest age, and the nematode community was characterized by the changes in the abundance instead of dominant genera in a temperate forest. A better understanding on the responses of soil nematode communities to forest secondary succession would improve our ability to protect biodiversity and strengthen forest services. Nevertheless, the responses of soil nematode community, plant community, soil microbial community and abiotic factor have not been evaluated simultaneously under forest secondary succession in subtropical forests.

Forest secondary succession affects the soil nematode community through multiple pathways. Firstly, forest secondary succession could directly mediate soil nematode by changing the structures of vegetation and soil microbial community (Scherber et al., 2010). A recent study reported that under forest secondary succession, the perennial woody (shrub) plant cover gradually increased but the cover and diversity of plants in the herb layer decreased (Su et al., 2021). As secondary stands develop, the increase in vegetation biomass could enhance belowground carbon allocation and subsequently soil organism activity (Francini et al., 2018; Morrien et al., 2017). Accordingly, a recent study reported that the microbial biomass carbon, diversity and richness of bacterial community significantly increased following the succession stages (Qu et al. 2020). Secondly, forest secondary succession can alter soil properties and competition of resources within a soil nematode community (Cesarz et al., 2013; Eisenhauer et al., 2013; Valladares et al., 2012). For example, natural forest succession affect soil pH and nutrient availability, and consequently soil nematode communities (Bautista-Cruz and del Castillo, 2005; Wang et al., 2021). While specific trophic levels of belowground food webs may depend on forest stand age in natural ecosystems (Morrien et al., 2017; Sohlenius, 2002; Valladares et al., 2012; Zhang et al., 2015), it is unclear how the structures of plant and soil microbial community, and environment conditions would affect the relationship between forest secondary succession and soil nematode communities.

The objective of this study is to explore how forest secondary succession could influence the abundance, diversity and community composition of soil nematode community in a subtropical forest. We examined the dynamics of soil nematode under different forest stand ages (4-5 years, early stand initiation; 8-12 years, canopy closure; 18-22 years, stem exclusion; 25-30 years, canopy transition; and 35-40 years, gap dynamics) under natural secondary succession, with primary forests (over 100 years) as references. We hypothesized that the abundance and diversity of soil nematode will increase with forest stand age, and that the structure of soil nematode community will be mainly regulated by changes in soil microbial community, soil properties and plant community during natural secondary succession.

\section{Materials And Methods}

Site description 
This study was conducted in the Wuyi Mountain range of Longyan municipality ( $24^{\circ} 46^{\prime}$ to $25^{\circ} 28^{\prime} \mathrm{N}$ and $116^{\circ} 16^{\prime}$ to $\left.116^{\circ} 57^{\prime} \mathrm{E}\right)$, Fujian Province, China. The region represents one of the largest natural subtropical forests in southeast China. The study area had a typical subtropical monsoon climate, with a mean annual temperature of $c a 20.1^{\circ} \mathrm{C}$ and mean annual precipitation of ca $1646 \mathrm{~mm}$. The soil is formed from granite and is classified as a red earth according to the Chinese Soil Classification System, equivalent to an Oxisol in the USDA Soil Taxonomy. The nature restoration developed through natural regeneration of local tree species after selective harvesting and firewood collection. Three subplots ( $5 \mathrm{~m} \times 5 \mathrm{~m}$ ) were randomly set up within each plot to examine the number of plant species, and then the percent cover of plant species level was investigated at the represent sampled stand (Su et al, 2021). The dominate tree species include Castanopsis carlesii, Castanopsis fargesii and Castanopsis fissa. In addition to dominant species, other tree species include Schima superba, Castanopsis faberi, Cinnamomum micranthum, Pinus massoniana, Sloanea sinensis, Cyclobalanopsis glauca, Cinnamomum camphora and Lithocarpus glaber (Su et al. 2021).

The design of the field experiment has previously been described by Su et al. (2021). In brief, the forest region suffered from severe typhoons, repetitive harvesting and firewood collection in the last few decades. Stand ages were mainly obtained from forest management records. Natural secondary forests standing for five succession stages were sampled in this study to represent a wide range of stand age groups, namely 4-5 years, early stand initiation (T4-5); 8-12 years, canopy closure (T8-12); 18-22 years, stem exclusion (T18-22); 25-30 years, canopy transition (T25-30); and 35-40 years, gap dynamics (T3540); with primary forests over 100 years as references $(T>100)$. The distance between selected stands was over $1 \mathrm{~km}$ in order to account for spatial heterogeneity.

Soil sampling

A $20 \times 30 \mathrm{~m}$ plot for each sampled stand was randomly set up to represent the stand. Similar climate among these stands provides an ideal chronosequence to study the effects of natural forest succession on ecosystem multifunctionality. Twelve soil cores $(0-10 \mathrm{~cm})$ were collected from each plot using an auger (2.5 cm inner diameter) in May 2019. The litter layer was removed prior to sample collection, and twelve soil cores were collected from each plot and composited. After the removal of visible plant residues, soil samples were passed through a 2-mm-mesh sieve, placed in an ice box and transported to the laboratory. Each sample was subdivided into two portions, one for the determination of basic soil properties and the other for nematode analysis.

Analysis of soil variables

Soil moisture was determined by oven-drying at $105^{\circ} \mathrm{C}$ for 24 hours. Soil pH was measured using a glass electrode (1/2.5 soil/water mixture) with a pH meter (Mettler Toledo, Greifensee, Switzerland). Soil exchangeable $\mathrm{NH}_{4}{ }^{+}-\mathrm{N}$ and $\mathrm{NO}_{3}{ }^{-}{ }^{-} \mathrm{N}$ were extracted with $1 \mathrm{M} \mathrm{KCl}(1: 5$ soil : $\mathrm{KCl}$ solution) and determined by an automated flow injection analyzer (Skalar San++, Holland, Netherlands). Soil available phosphorus (P) wac extrarted with NaHrC, and analvzed hv a cnertronhotometer (TU-1810, China). Soil microbial Loading [MathJax]/jax/output/CommonHTML/fonts/TeX/fontdata.js 
biomass carbon (MBC) was determined with fumigation-extraction method described by Wu et al. (1990). Soil total carbon $(\mathrm{C})$ and total nitrogen $(\mathrm{N})$ were determined with a CNS Macro Elemental Analyzer (LECO Corp, MI, USA). Soil microbial community was assessed by phospholipid fatty acids (PLFAs).

The PLFAs were extracted from the soil as described by Wan et al. (2014). The resultant fatty acid methylesters of soil samples were separated, identified and quantified by capillary gas chromatography. The abundance of each individual fatty acids was expressed as $\mathrm{nmol} \mathrm{g}^{-1}$ dry soil in a given sample against an internal standard (methylester C19:0; Sigma-Aldrich, Taufkirchen, Germany). The structure of microbial community was analyzed for each experimental year with a principal component analysis (PCA) based on the relative molar abundances of the entire fatty acids after standardizing to unit variance.

Extraction and examination of soil nematode

Soil nematode individuals were collected by direct funnel extraction from $100 \mathrm{~g}$ fresh soil, as described in a modified Baermann funnel protocol recommended by Whitehead and Hemming (1965). Soil nematode density was quantified by counting the number of individuals under a Motic microscope (40x and 400x). The taxonomic groups were identified using the diagnostic keys of 150 randomly selected specimens per soil sample under the Motic microscope (200x and 400x). All nematodes identified were assigned to $c-p$ values of 1-5 and four trophic groups of bacterivores (BF), fungivores (FF), herbivores (PF) and omnivores-predators (OP) according to http://Nemaplex.ucdavis.edu. Results of nematode population were expressed as total number of nematodes individuals per $100 \mathrm{~g}$ dry soil. Diversity indices of nematode were calculated by the following approaches: Shannon-Weaver diversity $\mathrm{H}^{\prime}=-\sum \mathrm{P} i(\ln \mathrm{P} 1)$, where $\mathrm{P} i$ is the proportion of individuals in the $i$-th taxon. Plant parasite index (PPI) was estimated as $\mathrm{PPI}=\sum V(i) \cdot f(i)$ for plant-parasitic nematode families, and used to evaluate soil health and the functional responses of soil nematodes to nature restoration (Bongers, 1990).

Statistical analyses

Differences between forest stand ages were tested using one-way ANOVA followed by Duncan's test. A non-metric multidimensional scaling (NMDS) was employed to visualize the structures of soil nematode, microbe and plant community using the 'vegan' package in R (version 3.5.2). The NMDS1 scores were conducted as the indicators for the community structure of soil nematode, microbe and plant. Structural equation modeling (SEM) was performed to analyze hypothetical pathways that may explain how forest ages affect soil nematode community structure using AMOS version 24.0 (Amos Development Corporation, Chicago, IL, USA). We classified all variables into five functional groups before SEM analyses, namely forest stand age, plant community (NMDS1 of entire plant species), soil environment (i.e. soil pH, bulk density and moisture), soil microbial community (NMDS1 of entire fatty acids) and soil nematode community (NMDS1 of entire nematode genera). All variables were natural log transformed prior to SEM analysis to reduce departure from normality and linearity. The relative contribution of soil nutrients to soil nematode density and diversity was further examined by aggregated boosted tree (ABT) 
analysis (De'ath, 2007), using the 'gbmplus' package in R. Statistical analyses were performed in SPSS 22.0 (IBM SPSS Statistics for Windows, Version 22.0. Armonk, NY, USA).

\section{Results}

Variations in soil properties

Soil $\mathrm{pH}$, bulk density, $\mathrm{NH}_{4}{ }^{+}-\mathrm{N}$ concentrations, $\mathrm{NO}_{3}{ }^{-}-\mathrm{N}$ concentrations and $\mathrm{MBC}$ were largely influenced by forest secondary succession (Table 1). Compared to $T>100$, soil pH was significantly higher in the all succession stages. Soil pH tended to increase with forest stand age. Soil bulk density, $\mathrm{NH}_{4}{ }^{+}-\mathrm{N}^{-} \mathrm{NO}_{3}{ }^{-}{ }^{-} \mathrm{N}$ and $\mathrm{MBC}$ concentrations increased with succession stages. There was no significant difference in the available $\mathrm{P}$, total $\mathrm{C}$ or $\mathrm{N}$ among forest stand ages.

Table 1

Soil properties during forest secondary succession

\begin{tabular}{|c|c|c|c|c|c|c|c|c|c|}
\hline $\begin{array}{l}\text { Forest } \\
\text { age }\end{array}$ & $\mathrm{pH}$ & $\begin{array}{l}\text { Bulk } \\
\text { density } \\
\left(\mathrm{g} \mathrm{cm}^{-}\right. \\
\text {3) }\end{array}$ & $\begin{array}{l}\text { Soil } \\
\text { moisture } \\
(\%)\end{array}$ & $\begin{array}{l}\mathrm{NH}_{4}^{+}- \\
\mathrm{N} \\
(\mathrm{mg} \\
\left.\mathrm{kg}^{-1}\right)\end{array}$ & $\begin{array}{l}\mathrm{NO}_{3}^{-}- \\
\mathrm{N} \\
(\mathrm{mg} \\
\left.\mathrm{kg}^{-1}\right)\end{array}$ & $\begin{array}{l}\text { Available } \\
\text { P } \\
\text { (mg kg- } \\
\left.{ }^{1}\right)\end{array}$ & $\begin{array}{l}\text { Total } \\
\mathrm{C} \\
(\mathrm{g} \\
\left.\mathrm{kg}^{-1}\right)\end{array}$ & $\begin{array}{l}\text { Total } \\
\mathrm{N}(\mathrm{g} \\
\left.\mathrm{kg}^{-1}\right)\end{array}$ & $\begin{array}{l}\text { MBC } \\
\left(\mathrm{mg} \mathrm{kg}^{-}\right. \\
\left.{ }^{1}\right)\end{array}$ \\
\hline T4-5 & $\begin{array}{l}4.28 \\
\pm \\
0.35 a\end{array}$ & $\begin{array}{l}0.92 \pm \\
0.15 \mathrm{ab}\end{array}$ & $\begin{array}{l}40.45 \pm \\
4.30 \mathrm{ab}\end{array}$ & $\begin{array}{l}5.60 \pm \\
0.83 b\end{array}$ & $\begin{array}{l}0.80 \pm \\
0.05 b\end{array}$ & $\begin{array}{l}2.10 \pm \\
0.14 a\end{array}$ & $\begin{array}{l}26.50 \\
\pm \\
5.04 a\end{array}$ & $\begin{array}{l}1.96 \\
\pm \\
0.29 a\end{array}$ & $\begin{array}{l}594.47 \\
\pm 4.47 \mathrm{~b}\end{array}$ \\
\hline T8-12 & $\begin{array}{l}4.47 \\
\pm \\
0.31 \mathrm{a}\end{array}$ & $\begin{array}{l}0.84 \pm \\
0.05 b\end{array}$ & $\begin{array}{l}43.74 \pm \\
5.95 a\end{array}$ & $\begin{array}{l}9.20 \pm \\
1.05 \mathrm{ab}\end{array}$ & $\begin{array}{l}1.35 \pm \\
0.36 a b\end{array}$ & $\begin{array}{l}2.75 \pm \\
0.38 a\end{array}$ & $\begin{array}{l}27.84 \\
\pm \\
6.87 a\end{array}$ & $\begin{array}{l}2.16 \\
\pm \\
0.51 \mathrm{a}\end{array}$ & $\begin{array}{l}751.03 \\
\pm \\
80.08 \mathrm{ab}\end{array}$ \\
\hline $\begin{array}{l}\text { T18- } \\
22\end{array}$ & $\begin{array}{l}4.54 \\
\pm \\
0.09 a\end{array}$ & $\begin{array}{l}1.04 \pm \\
0.09 a\end{array}$ & $\begin{array}{l}32.97 \pm \\
1.41 \mathrm{~b}\end{array}$ & $\begin{array}{l}9.06 \pm \\
2.30 \mathrm{ab}\end{array}$ & $\begin{array}{l}1.67 \pm \\
0.90 \mathrm{ab}\end{array}$ & $\begin{array}{l}2.53 \pm \\
0.50 \mathrm{a}\end{array}$ & $\begin{array}{l}24.00 \\
\pm \\
4.81 \mathrm{a}\end{array}$ & $\begin{array}{l}1.94 \\
\pm \\
0.14 a\end{array}$ & $\begin{array}{l}845.95 \\
\pm \\
40.95 a\end{array}$ \\
\hline $\begin{array}{l}\text { T25- } \\
30\end{array}$ & $\begin{array}{l}4.58 \\
\pm \\
0.11 \mathrm{a}\end{array}$ & $\begin{array}{l}0.89 \pm \\
0.14 a b\end{array}$ & $\begin{array}{l}37.66 \pm \\
6.93 \mathrm{ab}\end{array}$ & $\begin{array}{l}8.34 \pm \\
2.35 \mathrm{ab}\end{array}$ & $\begin{array}{l}1.02 \pm \\
0.26 \mathrm{~b}\end{array}$ & $\begin{array}{l}2.70 \pm \\
0.35 a\end{array}$ & $\begin{array}{l}24.44 \\
\pm \\
4.17 \mathrm{a}\end{array}$ & $\begin{array}{l}1.95 \\
\pm \\
0.38 a\end{array}$ & $\begin{array}{l}648.43 \\
\pm \\
133.88 \mathrm{~b}\end{array}$ \\
\hline $\begin{array}{l}\text { T35- } \\
40\end{array}$ & $\begin{array}{l}4.57 \\
\pm \\
0.11 \mathrm{a}\end{array}$ & $\begin{array}{l}0.95 \pm \\
0.10 a b\end{array}$ & $\begin{array}{l}42.40 \pm \\
5.72 \mathrm{a}\end{array}$ & $\begin{array}{l}10.23 \\
\pm \\
2.08 a\end{array}$ & $\begin{array}{l}0.92 \pm \\
0.23 \mathrm{~b}\end{array}$ & $\begin{array}{l}2.73 \pm \\
0.61 \mathrm{a}\end{array}$ & $\begin{array}{l}22.95 \\
\pm \\
0.60 \mathrm{a}\end{array}$ & $\begin{array}{l}1.75 \\
\pm \\
0.11 \mathrm{a}\end{array}$ & $\begin{array}{l}734.77 \\
\pm \\
46.66 \mathrm{ab}\end{array}$ \\
\hline $\begin{array}{l}T> \\
100\end{array}$ & $\begin{array}{l}4.11 \\
\pm \\
0.12 \mathrm{~b}\end{array}$ & $\begin{array}{l}1.04 \pm \\
0.09 a\end{array}$ & $\begin{array}{l}37.83 \pm \\
3.81 \mathrm{ab}\end{array}$ & $\begin{array}{l}10.10 \\
\frac{ \pm}{3.49 a}\end{array}$ & $\begin{array}{l}4.01 \pm \\
3.55 a\end{array}$ & $\begin{array}{l}2.35 \pm \\
0.77 a\end{array}$ & $\begin{array}{l}25.89 \\
\frac{ \pm}{3.85 a}\end{array}$ & $\begin{array}{l}2.00 \\
\pm \\
0.35 a\end{array}$ & $\begin{array}{l}862.58 \\
\pm \\
161.35 a\end{array}$ \\
\hline
\end{tabular}

Soil nematode abundance and diversity 
Soil nematode abundance varied greatly during forest secondary succession (Table 2 and TableS1). The total nematode abundance increased with forest stand ages, and reached a peak (574 individuals $100 \mathrm{~g}^{-}$

${ }^{1}$ dry soil) in the T35-40 age class (Fig. 1a). Compared to primary forests, total nematode abundance was significantly lower by $31.5-53.0 \%$ in the T4-5, T8-12 and T18-22 age classes. The abundances of trophic groups in varied from 50.3 to $96.8,30.7$ to $76.9,73.6$ to 237.1 and 152.8 to 303.8 individuals per $100 \mathrm{~g}$ dry soil for BF, FF, PF and OP, respectively, across forest secondary succession (Table 2). Similar to total nematode abundance, the abundances of all the trophic groups tended to increase with forest stand ages. Compared to the primary forests, natural secondary forests had lower abundances of PF across all stand ages, while the abundances of BF and OP were higher in the older stand age (Table 2). By contrast, soil nematode diversity was not significantly affected regardless of forest stand ages (Fig. 1b).

Table 2

The abundance of soil nematode (individuals $100 \mathrm{~g}^{-1}$ dry soil) during forest secondary succession

\begin{tabular}{|lllll|}
\hline Forest age & BF & FF & PF & OP \\
\hline T4-5 & $50.32 \pm 14.36 \mathrm{c}$ & $30.66 \pm 25.88 \mathrm{a}$ & $73.60 \pm 22.63 \mathrm{~b}$ & $152.75 \pm 28.67 \mathrm{c}$ \\
\hline T8-12 & $58.92 \pm 13.83 \mathrm{bc}$ & $43.89 \pm 23.55 \mathrm{a}$ & $79.19 \pm 26.99 \mathrm{~b}$ & $204.36 \pm 28.78 \mathrm{bc}$ \\
\hline T18-22 & $85.04 \pm 23.49 \mathrm{ab}$ & $21.79 \pm 8.04 \mathrm{a}$ & $128.28 \pm 42.89 \mathrm{~b}$ & $212.97 \pm 38.97 \mathrm{abc}$ \\
\hline T25-30 & $65.47 \pm 12.02 \mathrm{bc}$ & $32.65 \pm 4.10 \mathrm{a}$ & $106.82 \pm 20.90 \mathrm{~b}$ & $303.78 \pm 62.32 \mathrm{a}$ \\
\hline T35-40 & $96.84 \pm 19.96 \mathrm{a}$ & $39.23 \pm 20.48 \mathrm{a}$ & $163.16 \pm 96.10 \mathrm{ab}$ & $274.77 \pm 18.06 \mathrm{ab}$ \\
\hline T > 100 & $75.98 \pm 17.16 \mathrm{abc}$ & $76.90 \pm 63.14 \mathrm{a}$ & $237.13 \pm 71.06 \mathrm{a}$ & $264.55 \pm 79.06 \mathrm{ab}$ \\
\hline $\begin{array}{l}\text { BF, bacterivores; FF, fungivores; PF, herbivores; OP, omnivores-predators. Different letters indicate } \\
\text { statistically significant differences among treatments based on the Duncan's test }(P<0.05) .\end{array}$ \\
\hline
\end{tabular}

Nematode trophic composition and ecological index

Compared to the primary forests, forest stand age showed contrasting effects on the relative abundances of nematode trophic groups (Fig. 3). The relative abundance of BF was significantly lower in the primary forests than in the T18-22 age class whereas that of PF was significantly lower in the T8-12 age class. In contrast, the relative abundance of OP was higher in the T25-30 age class than in the primary forests whereas that of FF was not significantly affected by forest stand ages. The PPI index decreased with forest stand ages (Fig. 2). Compared to T4-5, the PPI index was significantly lower by $8.2-9.3 \%$ in the T18-22 and T25-30 age classes.

The structure of soil microbe, nematode and plant communities

For soil nematode, NMDS showed clear separation of younger age classes (T8-12 and T25-30) from the older age classes (T35-40 and T > 100), with the other two succession stages (T4-5 and T18-22) clustering together (Fig. 4a). The NMDS ordinations of soil microbial community and plant community Loading [MathJax]/jax/output/CommonHTML/fonts/TeX/fontdata.js from the other age classes (Fig. 4b, c). 
ABT analysis indicated that soil $\mathrm{NH}_{4}{ }^{+}-\mathrm{N}$ and available $\mathrm{P}$ were the most significant predictors for the abundance of soil nematode during secondary succession, with the relative contribution of $33.3 \%$ and $26.5 \%$, respectively. Soil available $\mathrm{P}$ and $\mathrm{NO}_{3}{ }^{-}-\mathrm{N}$ were the most significant predictors for soil nematode diversity during secondary succession, with the relative contribution of $43.2 \%$ and $23.5 \%$, respectively (Fig. 5).

The SEM was constructed to explore the direct and indirect effects of forest secondary succession on soil nematode community (Fig. 6). Forest secondary succession significantly influenced plant community structure, soil environment, soil microbial community and soil nematode community. Positive effects of forest stand age on the structures of plant and soil microbial communities, but negative effects on soil environment and nematode community structure, were detected. Forest secondary succession explained $39.9 \%, 22.1 \%$ and $39.7 \%$ of the total variances in plant community, soil environment and soil microbial community, respectively. Forest stand age, soil environment and the structures of plant and microbial community pathways explained $57.6 \%$ of total variance in soil nematode community structure. We also found that the microbial community structure was the main indirect pathway affecting soil nematode under forest secondary succession (Fig. 6). Overall, forest secondary succession could directly and indirectly influence soil nematode community through modifying the structures of plant and microbial communities, and the soil environment.

\section{Discussion}

Effects of nature restoration on soil nematode community

We found that the basal resources favored the soil nematode community, as well as the all trophic groups, both of which showed increasing patterns with forest ages during forest secondary succession. These findings agree well with previous reports (Keith et al., 2009; Morrien et al., 2017), which demonstrated that soil nematode populations peaked in the oldest age classes, mainly due to the increased root activity and ample food sources for soil nematode. For example, van Eekeren et al. (2009) observed that the abundance of herbivorous nematode was positively associated with fine root mass. Indeed, vegetation biomass accumulates substantially with forest stand ages, providing greater amounts of resources (leaves and litter) to soil nematode community. Consistent with previous studies (Banning et al., 2008; Orozco-Aceves et al., 2017), we found that soil microbial biomass carbon and the abundance of soil bacteria tended to increase with stand ages. Furthermore, litter accumulation and decomposition may improve the microclimates and soil properties (e.g. bulk density, soil moisture and $\mathrm{pH}$ ), thereby potentially increasing the population of nematode trophic groups (Qin et al., 2019). These findings indicated that the abundance of soil nematode in secondary succession may eventually reach a level similar to that of primary forest soils in subtropical forests. 
Contrary to our expectations, soil nematode diversity did not increase with forest stand age (Fig. 1b). This might be attributed to external disturbances which greatly alter the resource availability for soil nematode, consequently homogenizing these taxa across forest age classes (Francini et al. 2018). There are several possible reasons to explain this phenomenon. Firstly, in the same experimental site, Su et al. (2021) found that natural secondary forests had similar species diversities of shrub and bryophyte across all age classes. Secondly, soil biota in the higher trophic level require a longer time to adapt to changes in habitats than that in the lower trophic level (Valladares et al., 2012). Another possible explanation may be the distinct linkages among guilds in the soil food webs, because different trophic levels participated in differential interactions, including competition, predation, and mutualistic symbiosis (Yang et al., 2018). In this regard, soil nematodes may recover quickly after soil disturbances (Holtkamp et al., 2008) and are unaffected by forest stand age, despite an increase in plant biomass with time.

Our NMDS analysis of soil and plant communities separated intermediate age classes from primary forests. This suggested that the soil nematode and microbial communities showed an unstable structure during natural forest succession (Francini et al., 2018). We also observed that the community composition of soil nematode in the oldest stand age clustered together with the primary forests, although nematode abundance was lower in the T35-40 than primary forests. Soil nematode abundances and MBC were substantially higher in primary forests than in other forests, which is likely due to frequent disturbances in the young forests (Pickett et al., 2009).

Another important finding was that the value of plant parasite index decreased with forest stand ages. The plant parasite index, which denotes the proportion of plant parasites and free nematode, could reflect the health of soil and plant in the ecosystem (Bongers, 1990). These results suggest that natural ecosystem disturbance would shift the soil nematode community in a forest ecosystem and may threaten its ecosystem services.

Contributions of environmental factors to the soil nematode under nature restoration

In the present study, soil nutrient availability and vegetation growth were improved markedly during forest secondary succession. Soil nematode community composition was generally correlated with changes in abiotic soil parameters, such as pH, C and N availability, and soil moisture (Liu et al., 2016; Wang et al., 2021). The structure and composition of soil nematode communities might be associated with soil nutrients and biochemical factors, and their interactions with other factors (e.g., vegetation, soil, climate) (Chen et al., 2015; Wilschut and Geisen, 2020). This suggests that soil nematodes are sensitive indicators of temporal changes in soil characteristics and plant communities under disturbances (Williamson et al., 2005). Soil $\mathrm{NH}_{4}{ }^{+}-\mathrm{N}$ concentration likely increased with time, in response to increased plant biomass and organic matter turnover, (Banning et al., 2008), as we observed in primary forests. This will benefit the expansion of the soil nematode community in the older forest age classes (Chen et al., 2013).

We found that soil $\mathrm{NH}_{4}{ }^{+} \mathrm{N}$ and available $\mathrm{P}$ concentrations were key factors influencing soil nematode ahundance du rino forect cernndarv curcescinn and cnil available $\mathrm{P}$ and $\mathrm{NO}_{3}{ }^{-}$-N concentrations for soil Loading [MathJax]/jax/output/CommonHTML/fonts/TeX/fontdata.js 
nematode diversity. These results agree with the observation that changes in soil nutrient due to forest secondary succession could shape soil nematode density and diversity (Betts et al., 2017; Frouz et al., 2013). Future studies should devote more efforts to soil food web communities for a better understanding of the potential effects of artificial or natural disturbance on ecosystem function and health in forest soils.

The soil nematode community across six forest stand ages highlighted the overarching importance of microbe and vegetation in indirectly regulating the bottom-up control of food webs, relative to soil environment. The establishment of vegetation exerted a direct effect on soil nematode community by changing the quantity and quality of resource inputs (Cortois et al., 2017; De Deyn et al., 2007) and an indirect effect through their influence on soil microbes and habitat conditions (Liu et al., 2016). Soil physico-chemical properties are often correlated with plant growth; such interaction affects soil organisms directly and/or indirectly through changes in microclimates, the quality and quantity of litter and root exudates, as well as the interactions among components of soil food webs (Paul et al., 2010). Previous studies have reported that changes in the abundance and diversity of soil nematode can be attributed to alteration of the vegetation community during succession (Scherber et al., 2010; Thornton and Matlack, 2002). Changes in quantity and quality of vegetation with time strongly affected soil nematode communities through bottom-up (resource control) effect (Cesarz et al., 2013; Eisenhauer et al., 2013). The bottom-up forces mediated by soil microbial and plant communities can control soil nematode community structure (Eisenhauer et al., 2013; Scharroba et al., 2012), and the trajectories of soil nematode communities probably mirror the distribution of tree species (Cesarz et al., 2013; Zhang et al., 2015). Therefore, among the driving forces of soil nematode community, bottom-up effects mediated by plants and soil microbes could be important under forest secondary succession in subtropical forests.

At the whole system level, the responses of the soil nematode communities to forest secondary succession were much stronger than those of soil microbial community, plant community and soil environment (Fig. 6). Additionally, the responses of soil nematode and microbial communities were more sensitive to environment changes than that of soil properties and plant communities (Wang et al., 2021; Chen et al., 2015; Wilschut and Geisen, 2020). Expanding the knowledge on soil nematode in forest ecosystems would provide insights into sustainable forest management.

\section{Conclusions}

Our study provides strong evidence that the abundance of soil nematode gradually increased with forest stand ages, attributable to increased resource availability. Ecosystem disturbance had no effect on soil nematode diversity, but increased plant parasite index. The plant parasite index recovered to a level similar to that of primary forest. A potential shift in functional processes, as indicated by the increased plant parasite index under ecosystem disturbance, may affect ecosystem health in subtropical forests. Soil microbial and plant communities are critical to the community structure of soil nematodes, indicating that the bottom-up effects of the vegetation drive soil nematode community in subtropical forests. 
interactions to gain better understanding of the impacts on the soil food web during secondary succession in subtropical forests.

\section{Declarations}

\section{Acknowledgements}

The research was supported by the National Natural Science Foundation of China (Grant No. 31901165, 32071631,41907022 ) and Natural Science Foundation of Fujian Province, China (Grant No. 2020J01186, 2020J01138).

\section{Compliance with ethical standards}

Conflict of interest The authors declare no conflict of interest

\section{References}

1. Amossé J, Dózsa-Farkas K, Boros G, Rochat G, Sandoz G, Fournier B, Mitchell E, Le Bayon R (2016) Patterns of earthworm, enchytraeid and nematode diversity and community structure in urban soils of different ages. Eur J Soil Biol 73:46-58

2. Banning NC, Grant CD, Jones DL, Murphy DV (2008) Recovery of soil organic matter, organic matter turnover and nitrogen cycling in a post-mining forest rehabilitation chronosequence. Soil Biol Biochem 40(8):2021-2031

3. Bautista-Cruz A, del Castillo RF (2005) Soil Changes During Secondary Succession in a Tropical Montane Cloud Forest Area. Soil Sci Soc Am J 69(3):906-914

4. Betts MG, Wolf C, Ripple WJ, Phalan B, Millers KA, Duarte A, Butchart SHM, Levi T (2017) Global forest loss disproportionately erodes biodiversity in intact landscapes. Nature 547(7664):441-444

5. Bongers T (1990) The maturity index: an ecological measure of environmental disturbance based on nematode species composition. Oecologia 83(1):14-19

6. Bongers T, Bongers M (1998) Functional diversity of nematodes. Appl Soil Ecol 10(3):239-251

7. Calderon-Aguilera LE, Rivera-Monroy VH, Porter-Bolland L, Martínez-Yrízar A, Ladah LB, MartínezRamos M, Alcocer J, Santiago-Pérez AL, Hernandez-Arana HA, Reyes-Gómez VM, Pérez-Salicrup DR, Díaz-Nuñez V, Sosa-Ramírez J, Herrera-Silveira J, Búrquez A (2012) An assessment of natural and human disturbance effects on Mexican ecosystems: current trends and research gaps. Biodivers Conserv 21(3):589-617

8. Cesarz S, Ruess L, Jacob M, Jacob A, Schaefer M, Scheu S (2013) Tree species diversity versus tree species identity: Driving forces in structuring forest food webs as indicated by soil nematodes. Soil Biol Biochem 62:36-45

9. Chen D, Lan Z, Bai X, Grace JB, Bai Y, van der Heijden M (20130 Evidence that acidification-induced danlina in $n$ lant diunrcitu and nraduntivitu arn madinted by changes in below-ground communities 
and soil properties in a semi-arid steppe. J Ecol 101(5), 1322-1334

10. Chen D, Lan Z, Hu S, Bai Y (2015) Effects of nitrogen enrichment on belowground communities in grassland: Relative role of soil nitrogen availability vs. soil acidification. Soil Biol Biochem 89:99108

11. Cortois R, Veen GF, Duyts H, Abbas M, Strecker T, Kostenko O, Eisenhauer N, Scheu S, Gleixner G, De Deyn GB, van der Putten WH (2017) Possible mechanisms underlying abundance and diversity responses of nematode communities to plant diversity. Ecosphere 8(5):e01719

12. De'ath G (2007) Boosted trees for ecological modeling and prediction. Ecology 88(1):243-251

13. De Deyn GB, Van Ruijven J, Raaijmakers CE, De Ruiter PC, Van Der Putten WH (2007) Above- and belowground insect herbivores differentially affect soil nematode communities in species-rich plant communities. Oikos 116(6):923-930

14. Dickie IA, Yeates GW, St. John MG, Stevenson BA, Scott JT, Rillig MC, Peltzer DA, Orwin KH, Kirschbaum MUF, Hunt JE, Burrows LE, Barbour MM, Aislabie J (2011) Ecosystem service and biodiversity trade-offs in two woody successions. J Appl Ecol 48(4):926-934

15. Eisenhauer N, Dobies T, Cesarz S, Hobbie SE, Meyer RJ, Worm K, Reich PB (2013) Plant diversity effects on soil food webs are stronger than those of elevated $\mathrm{CO}_{2}$ and $\mathrm{N}$ deposition in a long-term grassland experiment. P Nati Acad Sci USA 110(17):6889-6894

16. Fahrig L (2003) Effects of Habitat Fragmentation on Biodiversity. Annu Rev Ecol Evol S 34(1):487515

17. Francini G, Hui N, Jumpponen A, Kotze DJ, Romantschuk M, Allen JA, Setälä H (2018) Soil biota in boreal urban greenspace: Responses to plant type and age. Soil Biol Biochem 118:145-155

18. Frouz J, Jílková V, Cajthaml T, Pižl V, Tajovský K, Háněl L, Burešová A, Šimáčková H, Kolaříková K, Franklin J, Nawrot J, Groninger JW, StahI PD (2013) Soil biota in post-mining sites along a climatic gradient in the USA: Simple communities in shortgrass prairie recover faster than complex communities in tallgrass prairie and forest. Soil Biol Biochem 67:212-225

19. Holtkamp R, Kardol P, van der Wal A, Dekker SC, van der Putten WH, de Ruiter PC (2008) Soil food web structure during ecosystem development after land abandonment. Appl Soil Ecol 39(1):23-34

20. Kardol P, Bezemer TM, van der Putten WH (2006) Temporal variation in plant-soil feedback controls succession. Ecol Lett 9(9):1080-1088

21. Keith AM, Brooker RW, Osler GHR, Chapman SJ, Burslem DFRP, van der Wal R (2009) Strong impacts of belowground tree inputs on soil nematode trophic composition. Soil Biol Biochem 41(6):10601065

22. Liu T, Whalen JK, Ran W, Shen Q, Li H (2016) Bottom-up control of fertilization on soil nematode communities differs between crop management regimes. Soil Biol Biochem 95:198-201

23. Morrien E, Hannula SE, Snoek LB, Helmsing NR, Zweers H, De Hollander M, Soto R,L, Bouffaud ML, Buée M, Dimmers W (2017) Soil networks become more connected and take up more carbon as nature restoration progresses. Nat Commun 8:14349

Loading [MathJax]/jax/output/CommonHTML/fonts/TeX/fontdata.js

Page $12 / 18$ 
24. Orozco-Aceves M, Tibbett M, Standish RJ (2017) Correlation between soil development and native plant growth in forest restoration after surface mining. Ecol Eng 106:209-218

25. Pan Y, Birdsey RA, Fang J, Houghton R, Kauppi PE, Kurz WA, Phillips OL, Shvidenko A, Lewis SL, Canadell JG, Ciais P, Jackson RB, Pacala SW, McGuire AD, Piao S, Rautiainen A, Sitch S, Hayes D (2011) A Large and Persistent Carbon Sink in the World's Forests. Science 333(6045):988

26. Paul M, Catterall CP, Pollard PC, Kanowski J (2010) Recovery of soil properties and functions in different rainforest restoration pathways. Forest Ecol Manag 259(10):2083-2092

27. Pickett STA, Cadenasso ML, Meiners SJ (2009) Ever since Clements: From Succession to Vegetation Dynamics and Understanding to Intervention. Appl Veg Sci 12(1):9-21

28. Qin Z, Xie J, Quan G, Zhang J, Mao D, Wang J (2019) Changes in the soil meso- and micro-fauna community under the impacts of exoticAmbrosia artemisiifolia. Ecol Res 34(2):265-276

29. Qu ZL, Liu B, Ma Y, Xu J, Sun H (2020) The response of the soil bacterial community and function to forest succession caused by forest disease. Funct Ecol 34:2548-2559

30. Renčo M, Čerevková A, Homolová Z, Gömöryová E (2015) Long-term effects on soil nematode community structure in spruce forests of removing or not removing fallen trees after a windstorm. Forest Ecol Manag 356:243-252

31. Scharroba A, Dibbern D, Hünninghaus M, Kramer S, Moll J, Butenschoen O, Bonkowski M, Buscot F, Kandeler E, Koller R, Krüger D, Lueders T, Scheu S, Ruess L (2012) Effects of resource availability and quality on the structure of the micro-food web of an arable soil across depth. Soil Biol Biochem 50:1-11

32. Scherber C, Eisenhauer N, Weisser WW et al (2010) Bottom-up effects of plant diversity on multitrophic interactions in a biodiversity experiment. Nature 468(7323):553-556

33. Sohlenius B (2002) Influence of clear-cutting and forest age on the nematode fauna in a Swedish pine forest soil. Appl Soil Ecol 19(3):261-277

34. Su X, Li S, Wan X, Huang Z, Liu B, Fu S, Kumar P, Chen HYH (2021) Understory vegetation dynamics of Chinese fir plantations and natural secondary forests in subtropical China. Forest Ecol Manag 483

35. Thornton CW, Matlack GR (2002) Long-term disturbance effects in the nematode communities of south Mississippi woodlands. J Nematol 34(2):88-97

36. Tilman D, Clark M, Williams DR, Kimmel K, Polasky S, Packer C (2017) Future threats to biodiversity and pathways to their prevention. Nature 546(7656):73-81

37. Valladares G, Cagnolo L, Salvo A (2012) Forest fragmentation leads to food web contraction. Oikos 121(2):299-305

38. Van Den Hoogen J, Geisen S, Routh D et al (2019) Soil nematode abundance and functional group composition at a global scale. Nature 572(7768):194-198

39. Van Der Putten WH, Bardgett RD, Bever JD et al (2013) Plant-soil feedbacks: the past, the present and future challenges. J Ecol 101(2):265-276 
40. Van Eekeren N, Van Liere D, De Vries F, Rutgers M, De Goede R, Brussaard L (2009) A mixture of grass and clover combines the positive effects of both plant species on selected soil biota. Appl Soil Ecol 42(3):254-263

41. Wan X, Huang Z, He Z, Yu Z, Wang M, Davis MR, Yang Y (2014) Soil C:N ratio is the major determinant of soil microbial community structure in subtropical coniferous and broadleaf forest plantations. Plant Soil 387(1-2):103-116

42. Wang J, Li M, Zhang X, Liu X, Li L, Shi X, Hu H, Pan G (2019) Changes in soil nematode abundance and composition under elevated $\left[\mathrm{CO}_{2}\right]$ and canopy warming in a rice paddy field. Plant Soil 445:425437

43. Wang J, Shi X, Li L, Zhang X (2021) Changes in soil nematodes in rhizosphere and non-rhizosphere soils following combined elevated $\left[\mathrm{CO}_{2}\right]$ and canopy warming in a winter wheat field. Geoderma 386:114907

44. Wardle DA, Bardgett RD, Klironomos JN, Setälä H, Van Der Putten WH, Wall DH (2004) Ecological Linkages Between Aboveground and Belowground Biota. Science 304(5677):1629

45. Whitehead AG, Hemming JR (1965) A comparison of some quantitative methods of extracting small vermiform nematodes from soil. Ann Appl Biol 55(1):25-38

46. Williamson WM, Wardle DA, Yeates GW (2005) Changes in soil microbial and nematode communities during ecosystem decline across a long-term chronosequence. Soil Biol Biochem 37(7):1289-1301

47. Wilschut RA, Geisen S (2020) Nematodes as Drivers of Plant Performance in Natural Systems. Trends Plant Sci 26(3):237-247

48. Wu J, Joergensen R, Pommerening B, Chaussod R, Brookes P (1990) Measurement of soil microbial biomass $C$ by fumigation-extraction-an automated procedure. Soil Biol Biochem 22(8):1167-1169

49. Yang B, Pang X, Bao W, Zhou K (2018) Thinning-induced canopy opening exerted a specific effect on soil nematode community. Ecol Evol 8(8):3851-3861

50. Zhang X, Guan P, Wang Y, Li Q, Zhang S, Zhang Z, Bezemer TM, Liang W (2015) Community composition, diversity and metabolic footprints of soil nematodes in differently-aged temperate forests. Soil Biol Biochem 80:118-126

\section{Figures}



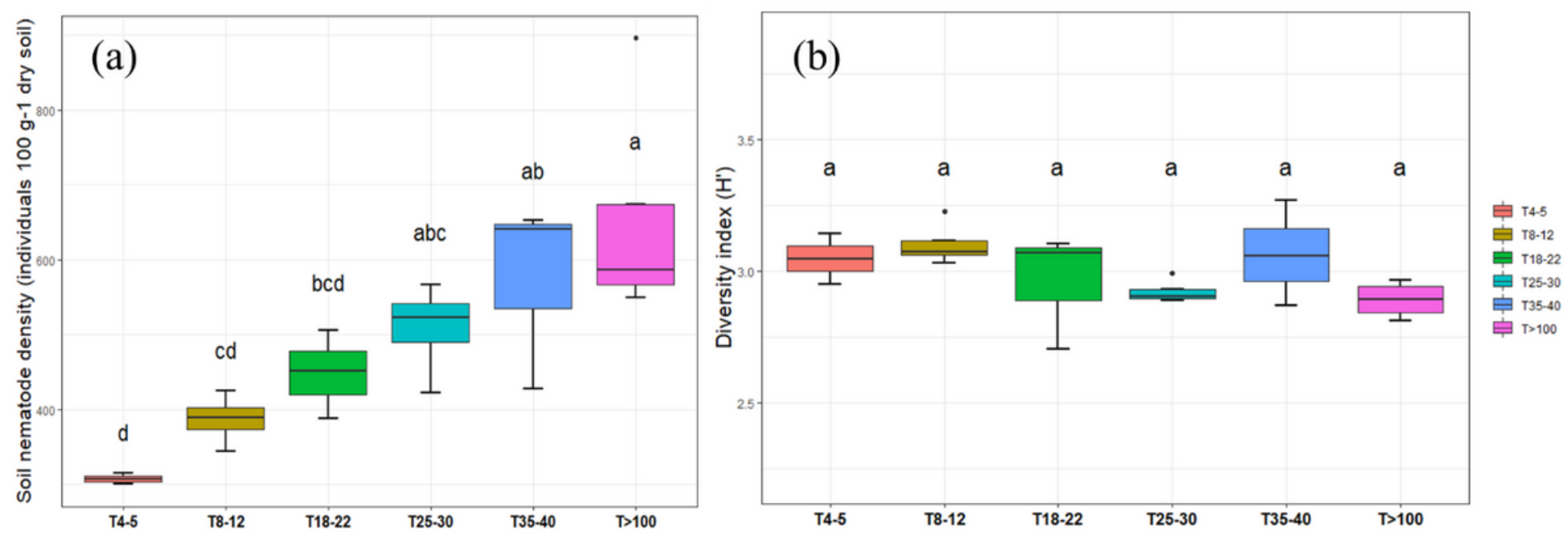

Figure 1

Total nematode abundance (individuals $100 \mathrm{~g}-1$ dry soil) and diversity during forest secondary succession. Different letters indicate significant difference between treatments at $P<0.05$.

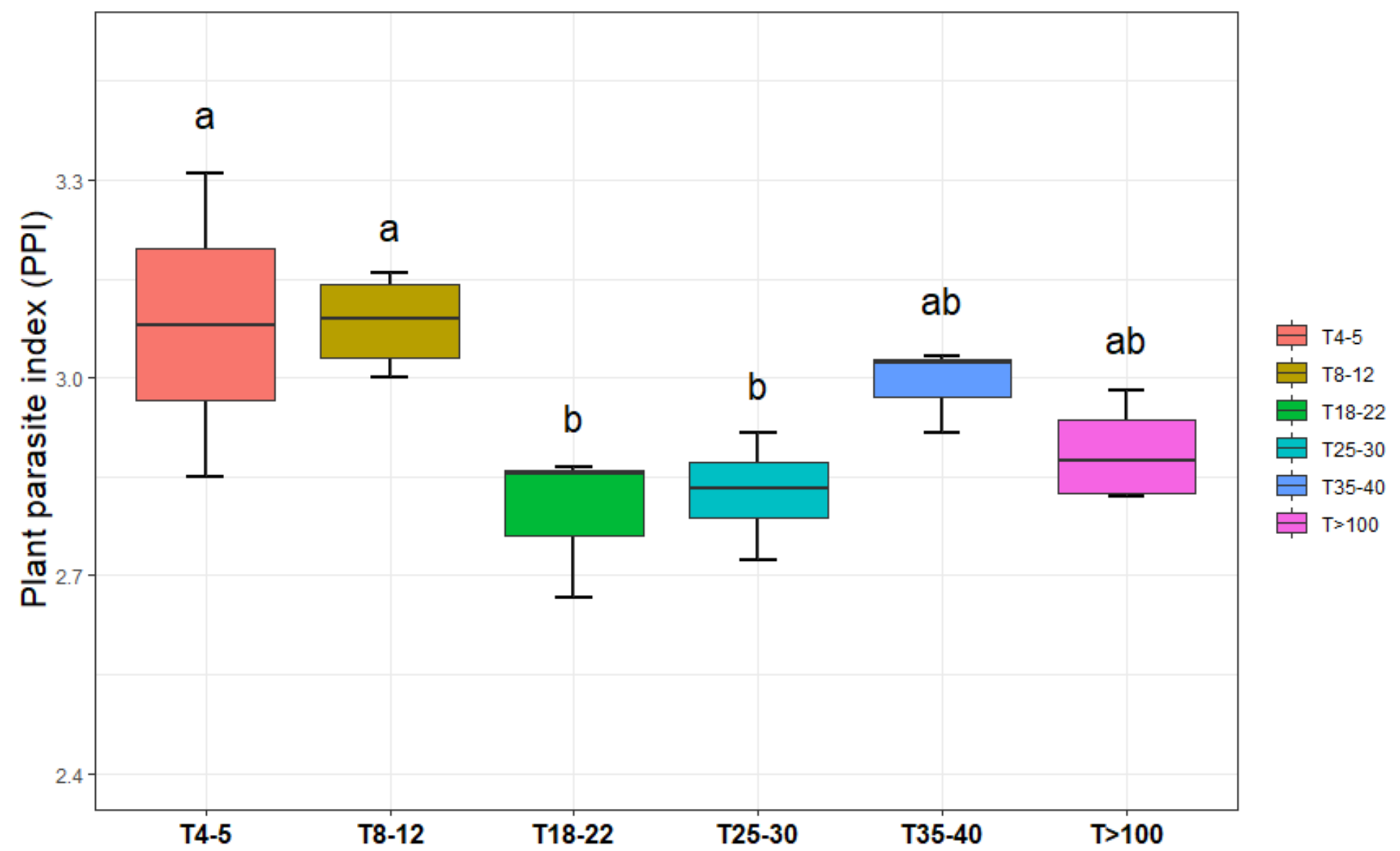

Figure 2

Plant parasite index (PPI) during forest secondary succession. Different letters indicate significant Loading [MathJax]/jax/output/CommonHTML/fonts/TeX/fontdata.js 


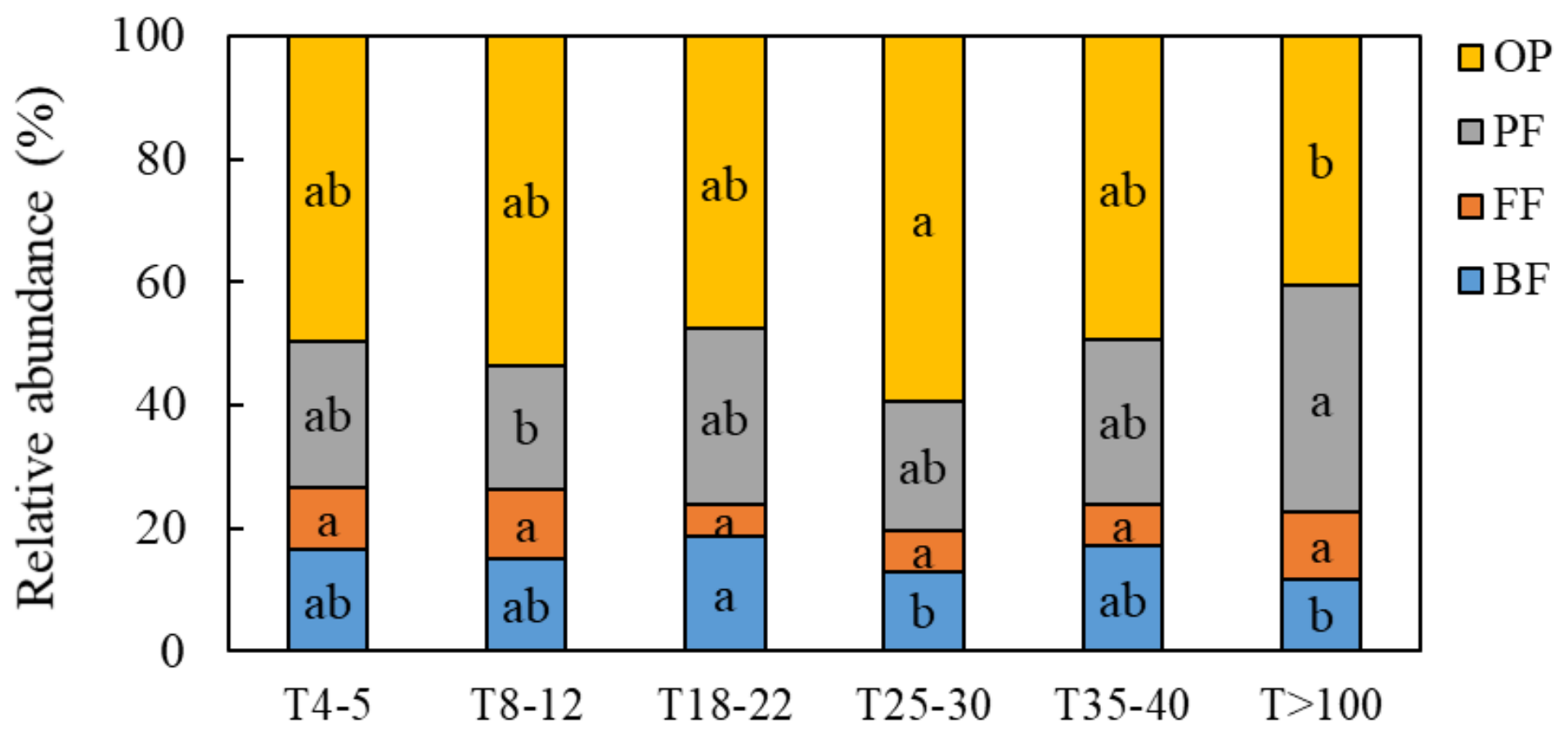

Figure 3

The relative abundances (\%) of soil nematode under forest secondary succession. Blue, orange, gray and yellow blocks represent bacterivores (BF), fungivores (FF), herbivores (PF) and omnivores-predators (OP), respectively. Different letters indicate significant difference between treatments at $P<0.05$. 


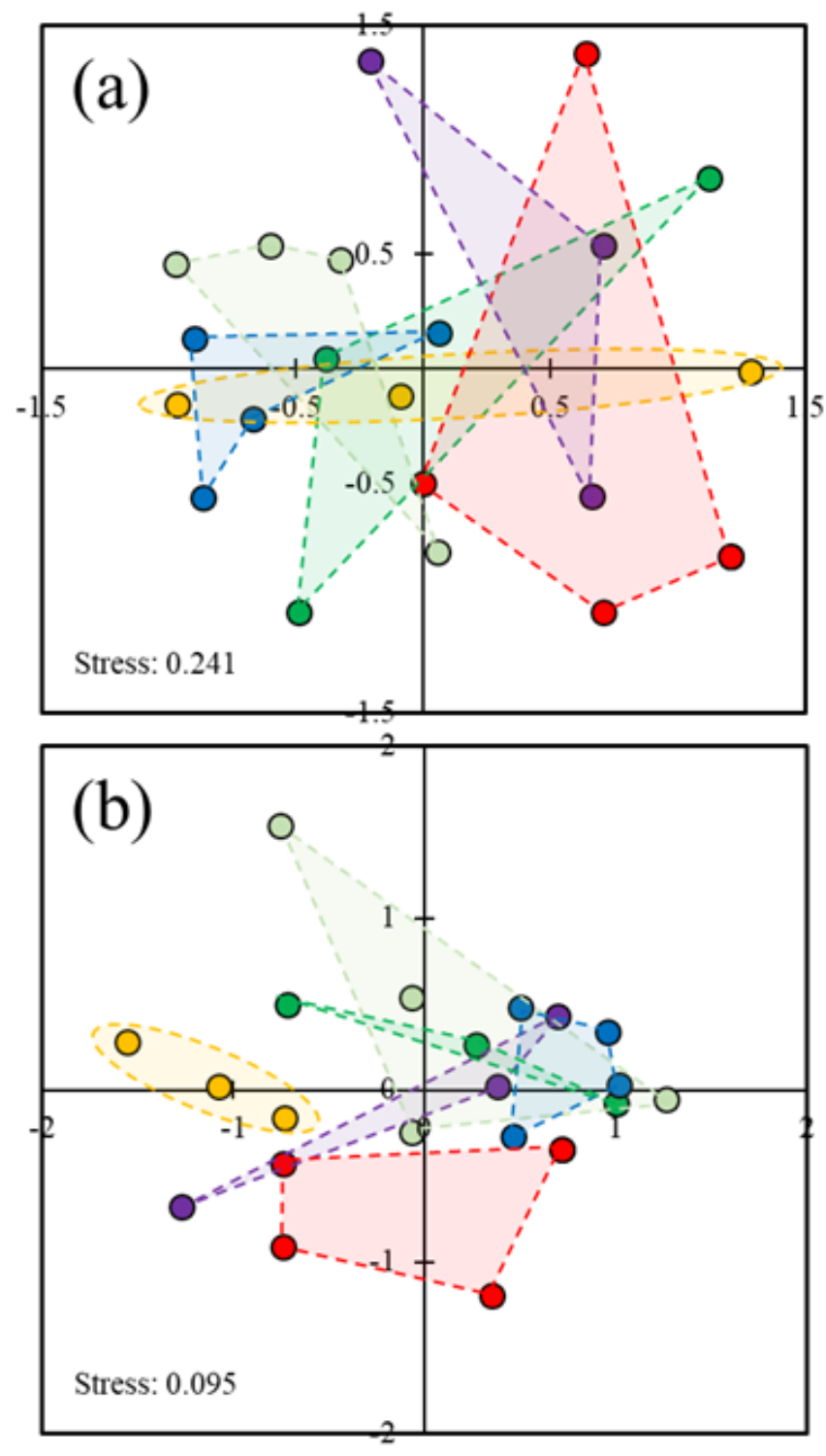

○ T4-5

ㄱ T8-12

- T18-22

- $\mathrm{T} 25-30$

- $\mathrm{T} 35-40$

- $\mathrm{T}>100$

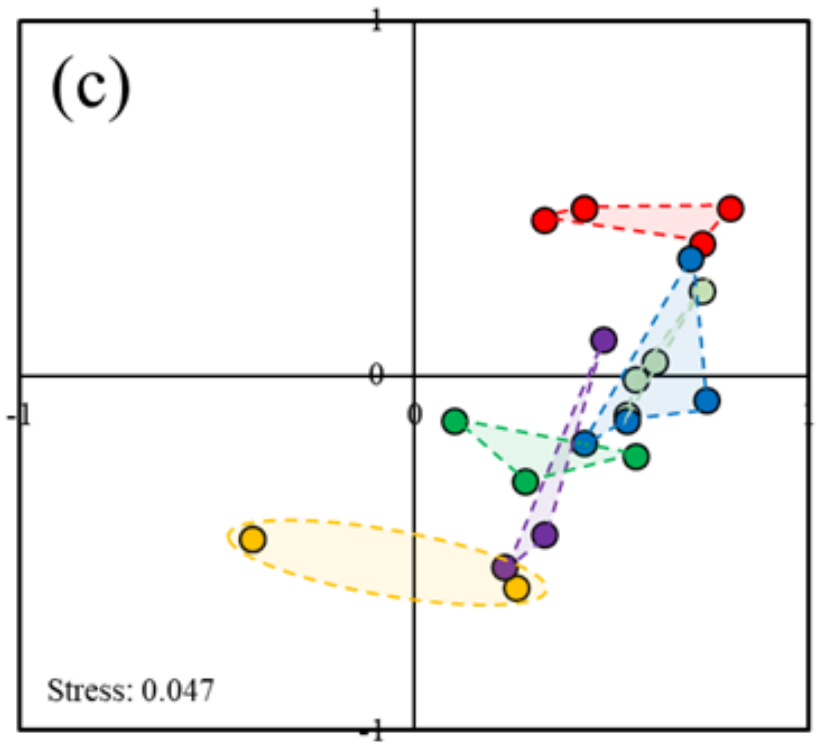

Figure 4

Non-metric multidimensional scaling ordinations (NMDS) based on the considered soil nematode community (a), microbe community (b) and plant community (c).
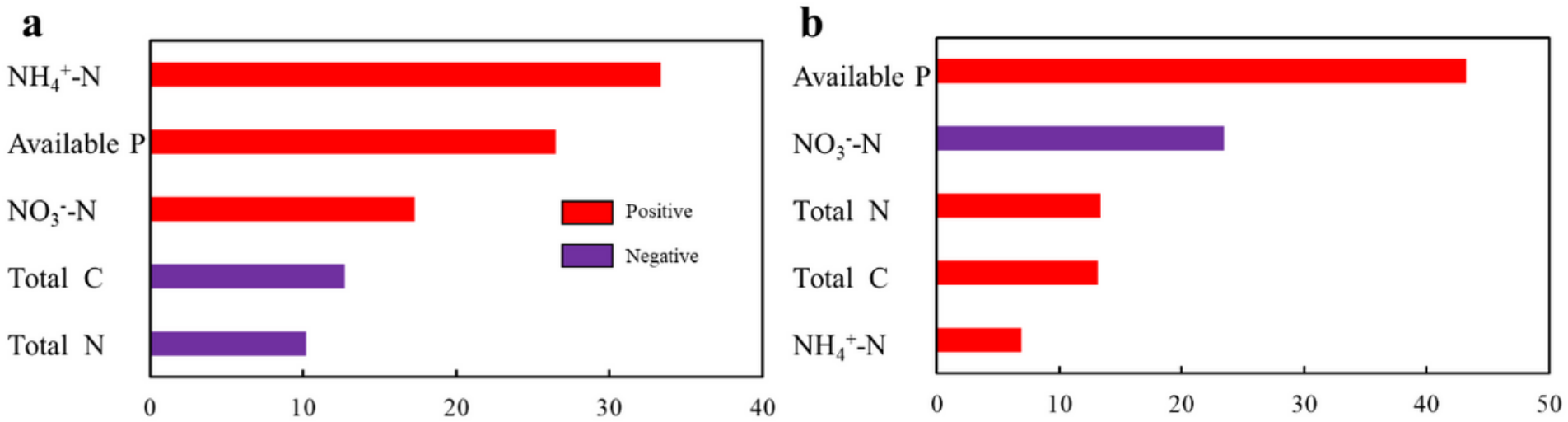

\section{Relative influence (\%)}


Figure 5

The relative contribution of soil nutrients to the nematode abundance (a) and diversity (b) during forest secondary succession using aggregated boosted tree (ABT) analysis.

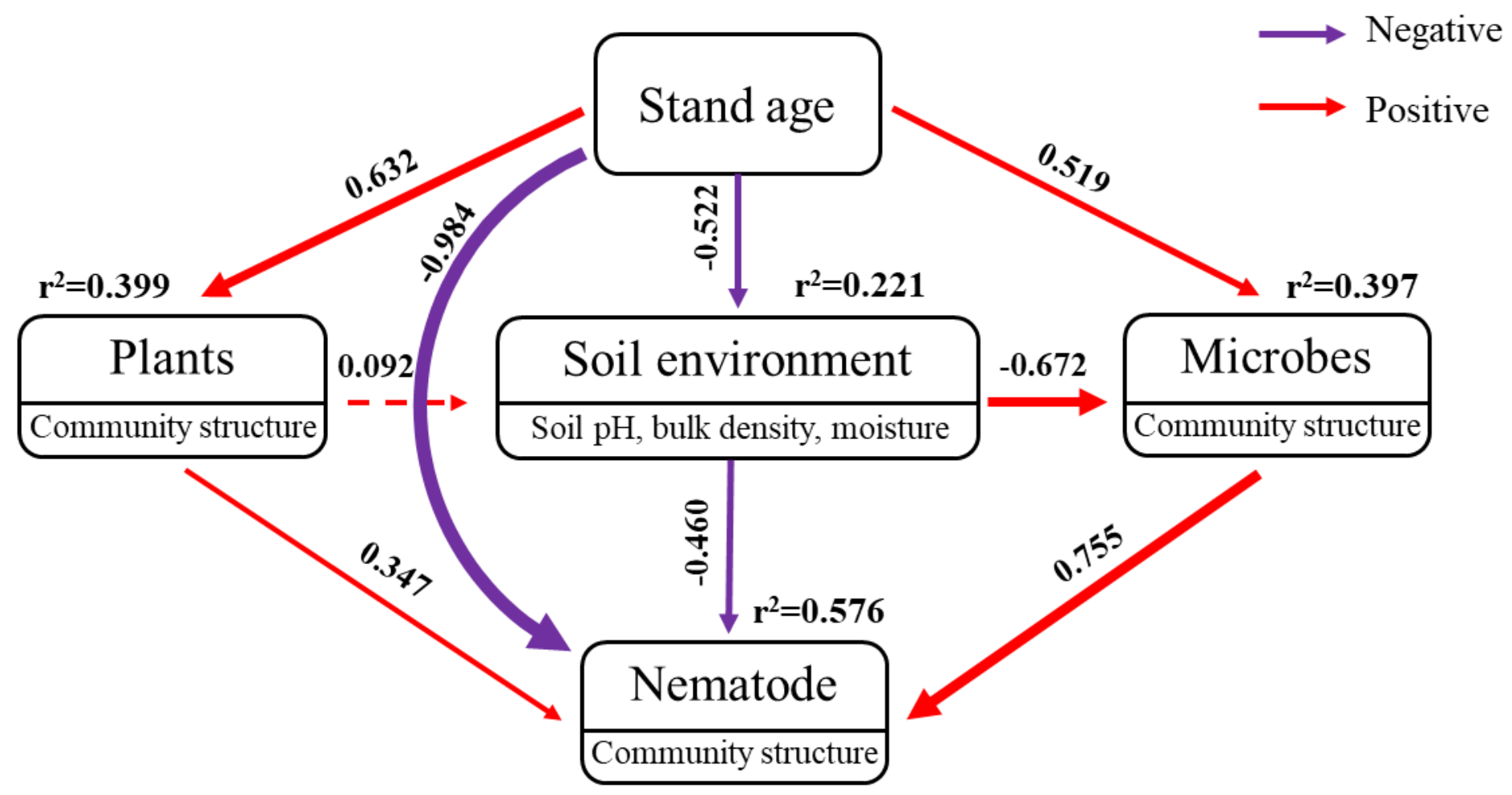

Figure 6

Structural equation modeling (SEM) analysis of forest secondary succession on soil micro-food webs in a subtropical forest. The results of the model fitting: Chi-square $(X 2)=10.772, P=0.292, d f=9, n=21$, comparative fit index $(\mathrm{CFI})=0.952$, root square mean error of approximation (RMSEA) $=0.102$. Purple and red arrows indicate negative and positive effects, respectively, while dashed arrows indicate nonsignificant effects.

\section{Supplementary Files}

This is a list of supplementary files associated with this preprint. Click to download.

- TableS1.xlsx 